\title{
The Value of Pancasila as a Filter on Foreign Culture in the Era of the Information Technology (IT) Development Social Media
}

\author{
Anggit Wahyu Wijanarko \\ Universitas Sebelas Maret, Surakarta, Indonesia \\ anggitw96@student.uns.ac.id
}

\section{Article History}

accepted 10/04/2021

approved 15/04/2021

published 20/04/2021

\begin{abstract}
This research is motivated by the increasingly advanced technological developments, especially in terms of the use of social media. Social media in the era of advances in information technology allows us to more freely relate to people in various parts of the world. This can have both positive and negative impacts. One thing that needs to be addressed is the easier it is for foreign cultures to enter through social media which can affect national identity. Therefore, Pancasila as the nation's view of life means that Pancasila is the guideline for every behavior of the Indonesian nation. The values contained in Pancasila should be able to become a filter against incoming foreign cultures due to the easier access to social media in the current era of technological advancement. The formulation and purpose of this research is to provide a descriptive analysis of the application of Pancasila values as a filter against foreign cultures in the era of advances in social media information technology. The method used in this research is qualitative with a descriptive analysis approach. The data analysis technique used is content analysis. The benefits of this research are; 1) this research can be used as a reference for further similar studies, 2) this research can be used as an illustration of the application of Pancasila values in the filtering of foreign cultures in the era of advancing social media technology..
\end{abstract}

Keywords: Pancasila value, information technology (IT), social media, foreign culture filter

\begin{abstract}
Abstrak
Penelitian ini dilatarbelakangi oleh semakin majunya perkembangan teknologi terutama dalam hal penggunaan media sosial. Media sosial di era kemajuan teknologi informasi memungkinkan kita dapat lebih leluasa dengan mudah berhubungan antar manusia di berbagai belahan dunia. Hal ini dapat menimbulkan dampak positif maupun negatif. Salah satu yang perlu disikapi adalah semakin mudahnya kebudayaan-kebudayaan asing yang masuk melalui media sosial yang dapat mempengaruhi jati diri bangsa. Maka dari itu pancasila sebagai pandangan hidup bangsa mempunyai arti bahwa pancasila menjadi pedoman bagi setiap perilaku bangsa Indonesia. Nilai-nilai yang terkandung dalam pancasila seharusnya dapat menjadi filter terhadap kebudayaan asing yang masuk akibat semakin mudahnya akses media sosial di era kemajuan teknologi saat ini. Rumusan dan tujuan dari penelitian ini adalah memberikan gambaran analisis secara deksriptif berkaitan dengan penerapan nilai-nilai pancasila sebagai filter terhadap kebudayaan asing di era kemajuan teknologi informasi media sosial.Metode yang digunakan dalam penelitian ini adalah kualitatif dengan pendekatan analisis deskriptif. Teknik analisis data yang digunakan adalah analisis konten. Manfaat dari penelitian ini adalah; 1) penelitian ini dapat digunakan untuk acuan penelitian-penelitian selanjutnya yang sejenis, 2) penelitian ini dapat digunakan sebagai gambaran penerapan nilai-nilai pancasila dalam filterasi kebudayaan asing di era kemajuan teknologi media sosial
\end{abstract}

Kata kunci : nilai Pancasila, teknologi informasi (IT), media sosial, filter kebudayaan asing

Social, Humanities, and Education Studies (SHEs): Conference Series https://jurnal.uns.ac.id/shes

p-ISSN 2620-9284

e-ISSN 2620-9292 


\section{PENDAHULUAN}

Perkambangan teknologi informasi (IT) di era revolusi industri 4.0 mempengaruhi berbagai bidang kehidupan seperti bidang ekonomi, pendidikan, politik, dan sosial-budaya. Teknologi informasi merupakan segala teknologi apapun yang membantu manusia salah satunya dalam mengomunikasikan dan/atau menyebarkan informasi. Contoh teknologi informasi adalah komputer, telepon, televisi, handphone, dan alat lain yang merupakan alat elektronik (Triyogo 2019). Kemudahan informasi melalui teknologi yang ada saat ini, tidak lepas dari tersedianya jaringan internet yang menghubungkan antar perangkat satu dengan perangkat lainnya. Internet telah menjadi kebutuhan sehari hari manusia khususnya di era globalisasi saat ini. Internet menyajikan segala informasi yang ingin didapatkan oleh penggunanya. Hal itu membuat internet mendapat posisi yang begitu penting bagi manusia di era kemajuan IT saat ini.

Didalam penggunaan internet tentunya tidak terlepas dari tersedianya media sosial, dimana sudah begitu banyak tercipta media sosial yang ada dimasyarakat, bahkan hampir di setiap negara memiliki media jaringan sosial lokal masing-masing. Media sosial inilah yang menjadi konsumsi bagi para pengguna Internet di Indonesia, hampir semua orang mempunyai media sosial (Nurrizka 2016). Kebanyakan dari pengguna media sosial di antaranya adalah remaja. Melansir dari situs Kemenkes RI (2018) Remaja menurut UU Perlindungan Anak adalah seseorang yang berusia antara 10-18 tahun, dan merupakan kelompok penduduk Indonesia dengan jumlah yang cukup besar (hampir $20 \%$ dari jumlah penduduk). Remaja merupakan calon pemimpin dan pengerak pembangunan di masa depan.

'Remaja merupakan masa yang sangat berharga bila mereka berada dalam kondisi kesehatan fisik dan psikis, serta pendidikan yang baik", ujar Menteri Kesehatan RI dalam paparannya yang disampaikan oleh Plt Dirjen Kesehatan Masyarakat Kemenkes, dr. Pattiselano Robert Johan, MARS, pada Seminar Kesehatan dan Gizi Remaja di Kantor Kementerian Kesehatan, Jakarta Selatan, Senin (15/5) (Kemenkes 2018)

Meski menjadi pengguna teknologi informasi berupa media sosial terbesar, remaja memiliki perkembangan mental yang belum stabil khususnya dalam menerima kebudayaan dari luar terutama di era globalisasi saat ini. Akibatnya banyak dari mereka para pengguna media sosial yang semakin canggih saat ini secara langsung memunculkan perubahan sosial di dalam masyarakat, seperti perubahan kebudayaan, dan perubahan gaya hidup. Sebagaimana Farley (1990) menyatakan bahwa perubahan sosial adalah perubahan perilaku, hubungan sosial, lembaga, dan struktur sosial pada kurun waktu tertentu (Sztomka 2004).

Remaja sangat berpotensi untuk terpengaruh pada kebudayaan asing yang dapat mengakibatkan kecenderungan dalam perubahan sosial mereka. Sebagaimana dijelaskan Kementrian Kesehatan RI (2018) remaja mudah dipengaruhi oleh salah satunya adalah media sosial sehingga rawan terpengaruh oleh perilaku yang tidak sehat, atau mendapatkan informasi yang tidak benar kemudian diterima sebagaimana adanya.

Terkadang perilaku perubahan sosial pada masyarkaat indonesia terkhusus para remaja tidak mencerminkan pada kepribadian bangsa atau mengalami penyimpangan. Meminjam pendapat Taufik Abdullah (2014) sesuatu perilaku dianggap menyimpang apabila tidak sesuai dengan nilai-nilai dan norma-norma sosial yang berlaku dalam masyarakat atau dengan kata lain penyimpangan (deviation) adalah segala macam pola perilaku yang tidak berhasil menyesuaikan diri terhadap kehendak masyarakat (Syahril Muhammad 2019). Kehendak masyarakat di Indonesia adalah memiliki kepribadian dan pandangan hidup yang sesuai dengan pancasila. Makna Pancasila sebagai pandangan hidup bangsa Indonesia adalah sebagai pedoman bagi seluruh masyarakat Indonesia dalam bersikap dan bertingkah laku sehari-hari 
(Anonim, Makna Pancasila Sebagai Pandangan Hidup 2020). Maka dari itu pancasila harus dapat dijadikan filter terhadap kebudayaan asing yang tersebar khususnya pada media sosial dalam jaringan internet yang begitu luas.

Dalam artikel ini akan dibahas mengenai rumusan masalah berkaitan dengan judul nilai pancasila sebagai filter terhadap kebudayaan asing di era kemajuan teknologi informasi (IT) media sosial yang memiliki rumusan masalah sebagai beriku;t 1) Bagaimana kondisi nilai pancasila di era perkembangan teknologi informasi media sosial saat ini? 2) Bagaimana penerapan nilai pancasila sebagai filter kebudayaan asing? 3) Bagaimana nilai pancasila sebagai filter kebudayaan asing di era kemajuan teknologi informasi (IT) media sosial.

\section{Teori}

\section{Nilai Pancasila}

Sebagai suatu dasar filsafat Negara maka sila-sila Pancasila merupakan suatu sistem nilai, oleh karena itu sila-sila Pancasila itu pada hakikatnya merupakan suatu kesatuan (Kaelan dan Zubaidi, 2007: 31). Pancasila memiliki serangkaian nilai, yaitu ketuhanan, kemanusiaan, persatuan, kerakyatan, dan keadilan. Nilai-nilai dasar Pancasila seperti ketuhanan, kemanusiaan, persatuan, kerakyatan, dan keadilan yang bersifat universal, objektif, artinya nilai-nilai tersebut dapat dipakai dan diakui oleh negara-negara lain. Pancasila bersifat subjektif, artinya bahwa nilai-nilai Pancasila itu melekat pada pembawa dan pendukung nilai Pancasila itu sendiri, yaitu masyarakat, bangsa, dan negara Indonesia.

Nilai-nilai Pancasila juga merupakan suatu pandangan hidup bangsa Indonesia. Pancasila juga merupakan nilai-nilai yang sesuai dengan hati nurani bangsa Indonesia, karena bersumber pada kepribadian bangsa. Nilai-nilai Pancasila ini menjadi landasan dasar, serta motivasi atas segala perbuatan baik dalam kehidupan sehari-hari dan dalam kenegaraan. Dalam kehidupan kenegaraan, perwujudan nilai Pancasila harus tampak dalam suatu peraturan perundangan yang berlaku di Indonesia. Karena dengan tampaknya Pancasila dalam suatu peraturan dapat menuntun seluruh masyarakat dalam atau luar kampus untuk bersikap sesuai dengan peraturan perundangan yang disesuaikan dengan Pancasila. berikut:

Adapun nilai-nilai yang terkandung dalam setiap sila Pancasila adalah sebagai

\section{Ketuhanan Yang Maha Esa}

Dalam sila Ketuhanan yang Maha Esa terkandung nilai bahwa Negara yang didirikan adalah sebagai pengejawantahan tujuan manusia sebagai makhluk Tuhan yang Maha Esa. Oleh karena itu segala hal yang berkaitan dengan pelaksanaan dan penyelengaraan Negara bahkan moral Negara, moral penyelengara Negara, politik Negara, pemerintahan Negara, hukum dan peraturan perundang-undangan Negara, kebebasan dan hak asasi warga Negara harus dijiwai nilai-nilai Ketuhanan Yang Maha Esa (Kaelan dan Zubaidi, 2007: 31-32).

\section{Kemanusiaan yang Adil dan Beradab}

Dalam sila kemanusiaan terkandung nilai-nilai bahwa negara harus menjunjung tinggi harkat dan martabat manusia sebagai makhluk yang beradab (Kaelan dan Zubaidi, 2007: 32). Sila kedua Pancasila mengandung nilai suatu kesadaran sikap moral dan tingkah laku manusia yang didasarkan pada norma-norma dan kebudayaan baik terhadap diri sendiri, sesama manusia, maupun terhadap lingkungannya.

\section{Persatuan Indonesia}

Sifat kodrat manusia monodualis yaitu sebagai makhluk individu dan sebagai makhluk sosial. Untuk itu manusia memiliki perbedaan individu, suku, ras, kelompok, golongan, maupun agama. Konsekuensinya di dalam Negara adalah beraneka ragam tetapi mengkatkan diri dalam suatu kesatuan dalam semboyan "Bhineka Tunggal Ika". 


\section{Kerakyatan yang Dipimpin oleh Hikmat Kebijaksanan dalam Permusyawaratan/Perwakilan}

Rakyat merupakan subjek pendukung pokok Negara (Kaelan dan Zubaidi, 2007: 35). Negara merupakan dari rakyat, oleh rakyat, dan untuk rakyat sehingga rakyat merupakan asal mula kekuasaan Negara. Dalam sila keempat terkandung nilai demokrasi yang harus dilaksanakan dalam kehidupan negara.

\section{Keadilan Sosial bagi Seluruh Rakyat Indonesia}

Konsekuensi nilai keadilan yang harus terwujud adalah: 1) keadilan distributif (hubungan keadilan antara Negara terhadap warga negaranya), (2) keadilan legal (keadilan antara warga Negara terhadap negara), dan (3) keadilan komutatif (hubungan keadilan antara warga negara satu dengan lainnya).

\section{Implementasi Nilai Pancasila}

Pancasila merupakan pedoman atau dasar kehidupan bersama di Indonesia. Pancasila menjadi landasan dari segala apapun. Dalam perkembangannya pancasila memiliki dinamika sejarah yang cukup beragam, mulai dari penggunaan bahkan penyimpangan yang terjadi dalam mengamalkan pancasila. Pada era saat ini pancasila digunakan oleh masyarakat indonesia sebagai landasan dalam berkehidupan berbangsa dan bernegara. Masyarakt Indonesia sadar bahwa pancasila itu sangat penting. Mereka mengimplementasikan Pancasila ke dalam kehidupan sehari-hari.

Implementasi nilai pancasila perlu untuk diperhatikan terutama oleh dunia pendidikan, karena pengajaran yang paling efektif dalam mengenal nilai-nilai pancasila adalah melalui dunia pendidikan.

Sila pertama Pancasila dengan sila pertamanya, adalah sebuah falsafah yang sesuai dan bersahabat dengan agama. Bangsa Indonesia sudah sepatutnya menyadari realitas kemajemukan Indonesia sebagai sebuah berkah dari Allah, yang perlu dikembangkan dan dilestarikan. Keberagaman semestinya tidak bersifat hierarkis, melainkan egaliter, dan oleh karena itu berimplikasi pada nilai etis toleransi. Sebagai umat beragama yang beriman dan bertakwa kepada Allah, sudah semestinya kita menanamkan nilai-nilai kebenaran, kebaikan, kejujuran, dan kemuliaan dalam diri, sehingga meningkatkan moral bangsa

Sila Kedua, Nilai yang terkandung dari sila kedua ini adalah nilai kemanusiaan. Perwujudan nilai kemanusiaan di sini tergambar pada nilai-nilai yang berkeadilan dan beradap yang terwujud sepertihalnya semangat saling menghargai, toleran, yang dalam perilaku seharai-hari didasarkan pada nilai-nilai moral yang tinggi. Dengan diterapkannya nilai pancasila pada sila kedua ini diharapkan akan mampu mengatasi permasalahan seperti tidak adanya toleransi, konflik antar golongan, pengangguran, kemiskinan, mafia kasus, korupsi, diskriminasi, dan kesenjangan sosial, tindakan kekerasan baik kekerasan baik fisik, verbal, vertikal, maupun horizontal.

Sila Ketiga, Indonesia adalah Negara yang kaya akan keberagaman suku, agama, bahasa, budaya, dan ras. Namun dengan terbentuknya NKRI, dimulailah komitmen bersama untuk terus membentengi keberagaman itu untuk mewujudkan Indonesia yang maju, adil, dan sejahtera. Itulah makna yang terkandung dari sila persatuan Indonesia. Sesuai dengan konstitusi tujuan negara ialah berkewajiban memberikan perlindungan kepada segenap tumpah darah Indonesia dan seluruh isinya dengan semangat persatuan tersebut. Perlakuan yang sama pada seluruh warga dimananapun berada haruslah dilakukan oleh pemerintah tanpa memandang latar belakang suku, ras, budaya, maupun agamanya. Warga negara dalam semangat kebersamaan seharusnya melakukan tindakan yang tetap menunjukkan sikap dan perbuatan yang NKRI untuk kebahagiaan dan kemajuan bersama. Semangat persatuan inilah yang harus terus dijaga agar NKRI tetap eksis, dan dapat menjadi kuat karena terbangun dari jalinan keberagaman yang harmonis.

Sila Keempat, Konstitusi mengamanatkan untuk newujudkan negara yang demokratis, yang mana kedaulatan diserahkan sepenuhnya kepada rakyat. Nilai yang 
terkandung Sila keempat pancasila adalah pedoman berdemokrasi Indonesia. Namun bagaimana cara mengimplementasikan demokrasi Indonesia masih dalam tahap pencarian identitas. Sejak merdeka, Indonesia telah melalui be-berapa tahapan demokrasi, yaitu demokrasi masa revolusi, demokrasi parlementer, demokrasi terpimpin, demokrasi era orde baru dan demokrasi era reformasi. Bagaimana dasar demokrasi khas Indonesia, dikemukakan oleh Soekarno di depan sidang BPUPKI 1 Juni 1945. Soekarno berpidato, “... Dasar itu ialah dasar mufakat, dasar perwakilan, dasar permusyawaratan. Negara Indonesia bukan satu negara untuk satu orang, bukan negara untuk satu golongan, walaupun golongan kaya. Tetapi kita mendirikan negara, "satu untuk semua", satu buat semua, semua buat satu. Saya yakin bahwa syarat yang mutlak untuk kuatnya negara Indonesia ialah per-musyawaratan perwakilan" (Amin Arjoso ed. 2002, hal 25 dalam Oetama, dkk). Dengan kata lain demokrasi Indonesia adalah musyawarah mufakat. Namun, dalam kenyataannya, pelaksanaan praktik politik di Indonesia belum mengutamakan permusyawaratan untuk mufakat. Sebaliknya, tren baru yang berkembang pada saat ini mengarah pada demokrasi transaksional. Uang menjadi kekuatan dalam menguasai politik, kelompok yang memiliki uang yang berlimpah yang akan menguasai dan memenangkan perpolitikan. Inilah yang pada akhirnya dikhawatirkan akan memberikan negara kepada kendali suatu kelompok tertentu. Urgensi Memahai dan.....Wendy Anugrah Octavian 127 Kondisi ini akan diperparah apabila demokrasi ekonomi, dan sosial tidak dilakukan, dan pemimpin yang visioner tidak dimiliki. Oleh karena itu, penting untuk mengkaji ulang gagasan demokrasi sesungguhnya sesuai dengan amanat sila ke empat pancasila.

Sila Kelima, Sila keadilan sosial mengandung makna bahwa setiap warganegara diperlakukan sama tanpa adanya perbedaan suku, ras, agama, bahasa, kaya dan miskin, maupun jabatan. Semua warganegara harus diperlakukan adil oleh negara. Perwujudan dari sila keadilan sosial ini dapat berupa penegakan mukum dengan asas keadilan bukan keuangan dan jabatan, tidak ada tekanan baik fisik maupun mental terhadap rakyat, mendapatkan kehidupan yang sejahterah atau terbebas dari kemiskinan, dan kebodohan, serta dari tekanan pihak asing. Pemerintah berpihak kepada rakyat yang harus dibela, bukan kepada golongan tertentu yang mempunyai kepentingan. Itulah prinsip keadilan yang terkandung dalam sila ke-lima. Namun sesungguhnya prinsip keadilan sosial bagi seluruh rakyat Indonesia menjadi anak tangga pertama yang harus dipijak dalam kehidupan berbangsa dan bernegara. Keadilan dalam konteks aturan, kebijakan, tindakan, dan perlakuan yang adil terhadap rakyatnya dapat membuat masyarakat leluasa bermusywarah dan bermufakat mencari solusi persoalan. Tegaknya keadilan membuat bangsa akan lebih mudah dalam menyatukan kekuatan untuk dapat mewujudkan kemakmurannya yang bermartabat. Keadilan juga akan mempertebal rasa kemanusiaan dan saling mencintai sesama ciptaan Tuhan. Akhirnya keadilan dapat membuat setiap orang tenang beribadah tanpa harus merasa terancam oleh kelompok lain yang berbeda keyakinan (Octavian 2018).

\section{Teknologi Informasi Media Sosial}

Istilah media sosial tersusun dari dua kata, yakni "media" dan "sosial". "Media" diartikan sebagai alat komunikasi (Laughey, 2007; McQuail, 2003). Sedangkan kata "sosial" diartikan sebagai kenyataan sosial bahwa setiap individu melakukan aksi yang memberikan kontribusi kepada masyarakat. Pernyataan ini menegaskan bahwa pada kenyataannya, media dan semua perangkat lunakmerupakan "sosial" ataudalam makna bahwa keduanya merupakan produk dariproses sosial (Fuchs 2014)

Manusia sebagai makhluk sosial membutuhkan interaksi dengan sesamanya untuk berbagi rasa, bertukar pikiran dan kehendak, baik secara langsung maupun tidak langsung, verbal maupun nonverbal. Hal ini secara alami tertanam dalam diri setiap individu, dan secara alami pula dilakukan sejak lahir. Dengan berkomunikasi 
manusia dapat saling berhubungan satu sama lain baik secara individu maupun kelompok dalam kehidupan sehari-hari. Hakikat komunikasi adalah proses pernyataan antar manusia (Effendy 2002).

Di era kemajuan teknologi saat ini manusia semakin memiliki kesempatan luas untuk bersosialisasi melalui jarak jauh. Komunikasi jarak jauh ini memungkinkan manusia untuk berhubungan dengan masyarakat di belahan dunia lain yang memiliki kebudayaan yang beragam. Perantara mereka untuk berhubungan dalam jarak jauh adalah tersedianya berupa perangkat lunak berbasis internet yang dinamakan dengan media sosial. Sosial media atau media sosial adalah sebuah media untuk bersosialisasi satu sama lain dan dilakukan secara online yang memungkinkan manusia untuk saling berinteraksi tanpa dibatasi ruang dan waktu (Rustian 2012).

Media sosial memiliki banyak macam dalam perkembangannya. Seseorang yang memiliki smartphone ditangannya pasti memiliki beberapa media sosial yang terpasang seperti; Facebook, Twitter, Path, Instagram, Youtube, Ome Tv, dan sebagainya. Kondisi ini seperti sebuah kelaziman yang mengubah bagaimana cara berkomunikasi pada era serba digital seperti sekarang. Jika dahulu, perkenalan dilaku-kan dengan cara konvensional, yakni (biasanya) diiringi dengan saling tukar kartu nama, sekarang setiap kita bertemu orang baru cenderung untuk bertukar alamat akun atau membuat pertemanan di media sosial (Mulawarman 2017).

Teknologi media sosial sekarang ini memiliki berbagai bentuk seperti misalnya majalah digital, forum internet, weblog, blog sosial, microblogging, wiki, jejaring sosial, podcast, foto atau gambar, video, rating dan bookmark sosial. Masing -masing memiliki kelebihannya sendiri seperti blogging, berbagi gambar atau foto, video blogging, wall-posting, berbagi musik atau lagu, chaatting, bahkan VolP atau Voice over IP, dan lain sebagainya. Macam-macam Jejaring Sosial - Jenis Media Sosial Berikut di bawah ini ada klasifikasi macammacam jejaring sosial berdasarkan fungsi dan kegunaannya: 1. Konten kolaborasi (contohnya, Wikipedia) 2. Blog dan microblog (contohnya, Twitter) 3. Situs jejaring sosial berita (contohnya, Digg) 4. Konten Video (contohnya, YouTube) 5. Situs jejaringan sosial (contohnya, Facebook) 6. Game dunia maya (contohnya, World of Warcraft) 7. Situs dunia sosial virtual (contohnya, Second Life) (Wilga Secsio Ratsja Putri t.thn.)

\section{Kebudayan Bangsa di Era Globalisasi}

Indonesia merupakan suatu negara dengan kebudayaan yang begitu kaya. Kekayaan kebudayaan itu yang membuat indonesia memiliki keberagaman baik dari segi etnis, suku, ras, agama, dan bahasa daerah (Ardiwijaja t.thn.)

Relasi Globalisasi dan Kebudayaan menurut Jan Aart Scholte (2001) mengamati proses globalisasi melalui lima indikator: (1) internasionalisasi, (2) liberalisasi ekonomi, (3) westernisasi, (4) demokratisasi, dan (5) deteritorialisasi. Di dalam indikator tersebut, tulisan ini fokus terhadap konsep internasionalisasi, westernisasi, dan deteritorialisasi. Internasionalisasi tertuju pada kejadian di suatu wilayah yang bisa mempengaruhi kejadian di beberapa wilayah lainnya. Pada intinya, konsep ini lebih menekankan pada konsep informasi dan kedekatan diantara elemenelemen masyarakat. Seiring dengan perkembangan teknologi informasi dan komunikasi, globalisasi yang beriringan dengan modernisasi menyebar ke seluruh penjuru dunia sebagai proses yang tak terelakkan. Globalisasi yang didorong oleh suatu teknologi informasi sedang menjalankan peran sebagai revolusi sosial yang memasuki semua sudut kehidupan. la menghilangkan batas-batas tradisional yang membedakan bisnis, media dan pendidikan, dan juga merombak struktur dunia usaha, serta mendorong pemaknaan ulang perdagangan dan investasi, kesehatan, hiburan, pemerintahan, perdagangan, pola produksi, bahkan pola relasi antarmasyarakat dan antarindividu. Inilah tantangan bagi semua bangsa, masyarakat dan individu di seluruh dunia bahkan di Indonesia (Mubah, 2011) 


\section{METODE}

Metode yang digunakan dalam penelitian ini adalah metode penelitian kualitatif dengan pendekatan deskriptif analisis. Melalui metode ini peneliti berusaha memaparkan secara jelas berdasarkan hasil penelitian yang telah dilaksanakan. Mengambil dari pendapat Nana Sudjana (2001) penelitian deskriptif adalah penelitian yang berusaha mendeskripsikan suatu gejala, peristiwa, kejadian, yang telah terjadi pada saat sekarang. Dalam penelitian ini akan disajikan berkaitan dengan bagaimana seharusnya pancasila sebagai pedoman hidup dan jati diri bangsa mampu memnjadi filter kebudayaan asing di era kemajuan teknologi informasi media sosial.

\section{HASIL DAN PEMBAHASAN \\ Media Sosial sebagai Salah satu Tempat Bersosialisasi dan Pertukaran Kebudayaan di Era Kemajuan IT}

Sejak dimulainya jejaring sosial pada tahun 1997, dengan diluncurkannya fitur blogging dan posting melalui web 2.0 dinamakan six degress.com. Tujuan dasar dari situs ini adalah untuk memfasilitasi orang-orang dalam hal konektivitas sosial melalui LinkedIn, My Space Orkut, Google talk, Skype, Hangout dan lain-lain. Cheung dan Lee [ 2010] menyatakan bahwa, " the driving forces behind online social networks are connections and community, and the usage is largely depended on subjective norm and social identity". yang artinya bahwa sosial media berkaitan dengan kineksi antar individu maupun komunitas dan penggunanya memiliki norma subjektif, jadi masingmasing individu yang berada di sosial media memiliki kecenderungan untuk melihat kebenaran yang menurutnya bagus untuk dirinya, sehingga pengaruh dari luar yang mungkin saja tidak sesuai dengan norma masyarakat atau bangsa akan mudah diterima begitu saja dan membentuk suatu identitas sosial tersendiri.

Dewasa ini, aktivitas daring (online) yang dilakukan oleh khalayak di seluruh penjuru dunia terbilang masif dan intensif. Ada banyak motif dan tujuan yang mendasari khalayak dalam mengakses layanan daring, khususnya media sosial. Masifnya masnyarakat di media sosial berarti juga masifnya masyarakat berhubungan antar satu dengan yang lain dalam jaringan yang begitu luas di sosial media. Masifnya hubungan sosial melalui media sosial pada era kemajuan IT ini mampu membawa ke suatu perubahan sosial berkaitan dengan identitas dan kebudayaan bangsa.

Perubahan sosial budaya dapat terjadi bila sebuah kebudayaan melakukan kontak dengan kebudayaan asing. Perubahan sosial budaya adalah sebuah gejala berubahnya struktur sosial dan pola budaya dalam suatu masyarakat. Perubahan sosial budaya merupakan gejala umum yang terjadi sepanjang masa dalam setiap masyarakat. Perubahan itu terjadi sesuai dengan hakikat dan sifat dasar manusia yang selalu ingin mengadakan perubahan. Hirschman mengatakan bahwa kebosanan manusia sebenarnya merupakan penyebab dari perubahan. Terdapat tiga faktor yang dapat mempengaruhi perubahan sosial, antara lain: 1. Tekanan kerja dalam masyarakat 2. Keefektifan komunikasi 3. Perubahan lingkungan alam. Perubahan budaya juga dapat timbul akibat timbulnya perubahan lingkungan masyarakat, penemuan baru, dan kontak dengan kebudayaan lain (Sodik t.thn.)

Keefektifan dalam komunikasi yang terjadi pada era kemajuan IT media sosial saat ini membuktikan bahwa potensi untuk semakin besarnya pengaruh kebudayaan asing yang dapat diterima oleh masyarakat Indonesia. Kita tidak mengetahui kebudayaan seperti apa yang datang dari luar Indonesia yang kemudian akan diterima bahkan menggantikan kebudayaan dan jati diri masyarakat, khususnya para remaja yang masih memiliki pemikiran yang cenderung belum stabil dan cenderung kurang mampu memfilter antara kebudayaan yang sesuai dengan kepribadian bangsa, atau yang bertentangan dengan kepribadian bangsa Indonesia. 


\section{Kebudayaan Asing yang Tidak Sesuai dengan Nilai Pancasila di Media Sosial Pada Era Kemajuan IT}

Kebudayaan sangat erat hubungannya dengan masyarakat. Kebudayaan adalah sesuatu yang akan mempengaruhi tingkat pengetahuan dan meliputi sistem ide atau gagasan yang terdapat dalam pikiran manusia, sehingga dalam kehidupan sehari-hari, kebudayaan itu bersifat abstrak. Sedangkan perwujudan kebudayaan adalah bendabenda yang diciptakan oleh manusia sebagai makhluk yang berbudaya, berupa perilaku dan benda-benda yang bersifat nyata, misalnya pola-pola perilaku, bahasa, peralatan hidup, organisasi sosial, religi, seni, dan lain-lain, yang kesemuanya ditujukan untuk membantu manusia dalam melangsungkan kehidupan bermasyarakat. Kebudayaan Barat sudah mendominanisasi segala aspek. Segala hal selalu mengacu kepada Barat. Peradaban Barat telah menguasai dunia. Banyak perubahan-perubahan peradaban yang terjadi di penjuru dunia ini. Kebudayan Barat hanya sebagai petaka buruk bagi Timur. Timur yang selalu berperadaban mulia, sedikit demi sedikit mulai mengikuti kebudayaan Barat. Masuknya budaya Barat ke Indonesia disebabkan salah satunya karena adanya krisis globalisasi yang meracuni Indonesia.

Masuknya budaya asing ke indonesia salah satunya disebabkan karena adanya krisis globalisasi yang meracuni indonesia. Pengaruh tersebut berjalan sangat cepat dan menyangkut berbagai bidang kehidupan. Tentu saja pengaruh tersebut akan menghasilkan dampak yang sangat luas pada sistem kebudayaan masyarakat. Begitu cepatnya pengaruh budaya asing tersebut menyebabkan terjadinya goncangan budaya (culture shock), yaitu: suatu keadaan dimana masyarakat tidak mamapu menahan berbagai pengaruh kebudayaan yang datang dari luar sehingga terjadi ketidakseimbangan dalam kehidupan masyarakat yang bersangkutan. Adanya penyerapan unsur budaya luar yang di lakukan secara cepat dan tidak melalui suatu proses internalisasi yang mendalam dapat menyebabkan terjadinya ketimpangan antara wujud yang ditampilkan dan nilai-nilai yang menjadi landasannya atau yang biasa disebut ketimpangan budaya. Teknologi yang berkembang pada era globasisasi ini mempengaruhi karakter sosial dan budaya dari lingkungan sosial. Pengaruh Budaya Asing terhadap Gaya Hidup Remaja Indonesia (Sodik t.thn.)

Pengaruh tersebut berjalan sangat cepat dan menyangkut berbagai bidang kehidupan. Tentu saja pengaruh tersebut akan menghasilkan dampak yang sangat luas pada sistem kebudayaan masyarakat. Begitu cepatnya pengaruh budaya asing tersebut menyebabkan terjadinya goncangan budaya (culture shock), yaitu suatu keadaan dimana masyarakat tidak mamapu menahan berbagai pengaruh kebudayaan yang datang dari luar sehingga terjadi ketidakseimbangan dalam kehidupan masyarakat yang bersangkutan. Adanya penyerapan unsur budaya luar yang di lakukan secara cepat dan tidak melalui suatu proses internalisasi yang mendalam dapat menyebabkan terjadinya ketimpangan antara wujud yang di tampilkan dan nilainilai yang menjadi landasannya atau yang biasa disebut ketimpangan budaya. Secara timbal balik, tiap peradaban akan berpengaruh satu sama lain.

Hukum sosial berlaku bagi semua peradaban. Peradaban yang maju, pada suatu masa, cenderung memiliki perngaruh yang luas bagi peradaban-peradaban lain yang berkembang belakangan. Perkembangan terknologi, terutama masuknya kebudayaan asing (barat) tanpa disadari telah menghancurkan kebudayaan lokal. Minimnya pengetahuan menjadi pemicu alkulturasi kebudayaan yang melahirkan jenis kebudayaan baru. Masuknya kebudayaan tersebut tanpa disaring oleh masyarakat dan diterima secara mentah. Akibatnya kebudayaan asli masyarakat mengalami degradasi yang sangat luar biasa. Budaya asing yang masuk keindonesia menyebabkan multi efek. Budaya Indonesia perlahan-lahan semakin punah. Berbagai iklan yang mengantarkan kita untuk hidup gaul dalam konteks modern dan tidak tradisional sehingga memunculkan banyaknya kepentingan para individu yang mengharuskan berada diatas kepentingan orang lain. Akibatnya terjadi sifat individualisme semakin 
berpeluang untuk menjadi budaya kesehariannya. Ini semua sebenarnya terhantui akan praktik budaya yang sifatnya hanya memuaskan kehidupan semata.

Di zaman sekarang ini manusia hidup dalam tingkat Hedonisme yang sangat tinggi berpikir dalam jangka pendek hanya mencari kepuasaan belaka dimana kepuasaan tersebut yang menyesatkan umat islam untuk berprilaku. Salah satu contoh Serdehana sesuai dengan kenyataan. Dari cara berpakaian banyak remaja- remaja kita yang berdandan seperti selebritis yang cenderung ke budaya Barat. Mereka menggunakan pakaian yang minim bahan yang memperlihatkan bagian tubuh yang seharusnya tidak kelihatan. Pada hal cara berpakaian tersebut jelas- jelas tidak sesuai dengan kebudayaan kita.

Tak ketinggalan gaya rambut mereka dicat beraneka warna. Pendek kata orang lebih suka jika menjadi orang lain dengan cara menutupi identitasnya. Tidak banyak remaja yang mau melestarikan budaya bangsa dengan mengenakan pakaian yang sopan sesuai dengan kepribadian bangsa. Jika pengaruh di atas dibiarkan, apa jadinya Moral generasi bangsa kita, timbul tindakan anarkis antara golongan muda. dengan adanya budaya barat atau budaya asing di Indonesia, dapat membawa dampak bagi Indonesia. Dampak masuknya budaya asing antara lain. terjadi perubahan kebudayaan, pembauran kebudayaan, modernisasi, keguncangan budaya, melemahnya nilai-nilai budaya bangsa. Dampak tersebut membawa pengaruh besar bagi Indonesia, baik dari segi postif, maupun negatif. Indonesia, masih terlalu lemah dalam menyaring budaya yang baik di ambil dengan yang tidak, "maka kita semua sebagai warga Indonesia wajib membanggakan apa saja yang sudah menjadi budaya kita sendiri", jangan sampai melupakan budaya lama dengan sudah menemukan budaya baru. Masuknya budaya asing ke suatu negara sebenarnya merupakan hal yang wajar, asalkan budaya tersebut sesuai dengan kepribadian bangsa namun kita harus tetap menjaga agar budaya kita tidak luntur. Langkah-langkah untuk mengantisipasinya adalah antara lain dengan cara, Menumbuhkan semangat nasionalisme yang tangguh, misal semangat mencintai produk dalam negeri, Menanamkan dan mengamalkan nilai- nilai Pancasila dengan sebaik- baiknya, Melaksanakan ajaran Agama dengan sebaik- baiknya dan Selektif terhadap pengaruh globalisasi di bidang politik, ideologi, ekonomi, sosial budaya bangsa. Sebagai identitas bangsa, budaya lokal harus terus dijaga keaslian maupun kepemilikannya agar tidak dapat diakui oleh negara lain. Walaupun demikian, tidak menutup kemungkinan budaya asing masuk asalkan sesuai dengan kepribadian negara karena suatu negara juga membutuhkan input-input dari negara lain yang akan berpengaruh terhadap perkembangan di negaranya.

Pancasila Sebagai Filter Kebudayaan Asing yang Terdapat Pada Media Sosial di Era Kemajuan IT

Presiden Soekarno pada saat berpidato dalam sidang Badan Penyelidik Usaha Persiapan Kemerdekaaan Indonesia (BPUPKI) tanggal 1 Juni 1945, pernah mengatakan mengenai pentingnya bangsa Indonesia memiliki sebuah "philosofische gronslaag" atau filosofi dasar yang memuat pandangan tentang dunia dan kehidupan (weltanschauung). Menurutnya dasar negara dan ideologi nasional tersebut, merupakan suatu hal yang abadi yang harus tetap dipertahankan selama berdirinya negara (Kementrian komunikasi dan informatika RI 2011)

Ungkapan dari presiden pertama sekaligus Proklamator Republik Indonesia tersebut, jelas memperlihatkan mengenai pentingnya dasar negara dan ideologi nasional sebagai landasan berdiri dan tegaknya sebuah negara. Oleh sebab itu, perumusan dasar negara Indonesia dilakukan melalui penggalian yang mendalam terhadap pandangan hidup dan falsafah hidup bangsa Indonesia yang mencerminankan nilai-nilai peradaban, kebudayaan, dan keluhuran budi yang mengakar dan teranyam dalam kehidupan bangsa Indonesia. Hal itu pulalah yang 
kemudian menjadi landasan dari lahirnya Pancasila sebagai dasar negara dan ideologi bangsa Indonesia (Yudhanegara 2015)

Di era kemajuan teknologi informas memunculkan era globalisasi yang mendatangkan dampak pada perilaku manusia yang disebut sebagai digital native. Helsper \& Enyon (2009) mengatakan bahwa digital native adalah generasi muda yang lahir saat internet telah menjadi bagian hidup mereka. Kehidupan mereka telah dikelilingi oleh internet sejak masih dalam kandungan hingga awal kelahiran mereka. Kemudian, tampilan foto bayi yang baru lahir tersebut sudah menjadi penduduk dunia maya. Foto bayi tersebut mulai tersebar di media sosial, seperti Facebook, Whatsapp group, Line, atau Instagram. Keikutsertaan mereka dinisbatkan di dunia maya sebagai digital native (Supratman 2018). Hal ini dapat memunculkan dampak negatif berupa sifat individualistik. Dikarenakan dari ketetarikan manusia sekarang bukan kepada lingkungan sosial dimana dia berada akan tetapi lebih kepada dunia maya. Globalisasi seakan telah mampu menciptakan hubungan interpersonal masyarakat Indonesia menjadi lebih individualistik, mementingkan diri sendiri, dan pragmatis (Yudhanegara 2015).

Di era globalisasi, dunia ibarat menjadi sebuah komunitas global yang hidup dan saling berinteraksi satu dengan yang lainnya, tidak memandang apakah negara tersebut maju atau berkembang, desa atau pun kota, semuanya akan saling berinteraksi. Selain itu, globalisasi mampu menciptakan peningkatan keterkaitan dan ketergantungan antar bangsa dan antar manusia di seluruh dunia. Akibatnya, tidak jarang banyak pengaruh yang masuk dari luar baik yang memiliki nilai positif maupun negatif. Perkembangan globalisasi, mampu memberikan pengaruh yang besar terhadap nilai-nilai yang telah berkembang di masyarakat. Bahkan dalam konteks yang lebih luas globalisasi mampu menghancurkan nilai-nilai yang telah ada di masyarakat, seperti nilai sosial-budaya, ideologi, agama, politik, dan ekonomi (Yudhanegara 2015)..

Ada tiga unsur utama yang senantiasa bergerak dalam era globalisasi seperti sekarang ini, yaitu unsur manusia, unsur barang dan modal, serta informasi. Melalui ketiga gerak tersebut, apa yang terjadi pada dunia luar akan dapat kita ketahui. Rumah-rumah kita akan terbuka terhadap dunia luar secara keseluruhan melalui media-media seperti televisi, surat kabar, telepon, internet dan lain sebagainya. Akibatnya, kita tidak bisa tertutup lagi terhadap pengaruh yang datang dari luar. Sehingga mau tidak mau, mereka harus siap menerima segala hal baru yang masuk ke negaranya, termasuk bangsa Indonesia (Yudhanegara 2015).

Masuknya akses informasi khususnya melalui media sosial akan berdampak pada keterpengaruhannya masyarakat terhadap kebudayaan asing yang sangat bebas dan tidak mampu dibendung. Seperti yang kita ketahui bahwa akses informasi dari luar tidak mampu dihentikan maka perlu adanya solusi alternatif agar jati diri bangsa Indonesia tetap terjaga sebagaimana sesuai norma-norma yang ada di masyarakat. Maka dari itu Pancasila yang merupakan ideologi sekaligus sebagai kepribadian bangsa harus dapat menjdai filter kebudayaan-kebudayaan asing yang masuk di tengah-tengah masyarakat akibat dampak dari adanya perkembangan teknologi informasi khsususnya media sosial.

Talcott Parsons (2007), seorang Sosiolog asal Amerika dalam bukunya yang berjudul Social System (sistem sosial) mengatakan bahwa jika suatu masyarakat ingin tetap eksis dan lestari, ada empat paradigma fungsi (function paradigm) yang harus terus dilaksanakan oleh masyarakat bersangkutan. Antara lain:

1. Pattern Maintenance (pola pemeliharaan), yaitu kemampuan memelihara sistem nilai budaya yang dianut dan berlaku di dalam masyarakat, karena budaya pada hakikatnya merupakan endapan dari perilaku manusia. Budaya masyarakat itu akan berubah karena terjadi transformasi nilai dari masyarakat terdahulu ke masyarakat baru atau pun karena masuknya pengaruh budaya dari luar, tetapi dengan tetap memelihara nilai-nilai yang dianggapnya luhur, 
budaya lama akan tetap bertahan meskipun akan terbentuk masyarakat baru yang lain

2. Kemampuan masyarakat beradaptasi dengan dunia yang berubah dengan cepat. Sejarah membuktikan banyak peradaban masyarakat yang telah hilang karena tidak mampu beradaptasi dengan perubahan dunia. Padahal menurut Parsons, masyarakat yang mampu menyesuaikan diri dengan perubahan serta mampu memanfaatkan peluang yang timbul, maka dialah yang akan unggul.

3. Adanya fungsi integrasi dari unsur-unsur masyarakat yang beragam secara terus-menerus, sehingga terbentuk kekuatan sentripetal yang akan kian menyatukan masyarakat itu. Artinya, sebuah sistem yang ada di dalam masyarakat, harus mampu mengatur dan menjaga antar hubungan bagianbagian yang menjadi komponennya.

4. Keempat, masyarakat perlu memiliki goal attainment atau tujuan bersama yang dari masa ke masa bertransformasi karena terus diperbaiki oleh dinamika masyarakatnya dan oleh para pemimpinnya. Jika negara kebangsaan Indonesia terbentuk oleh kesamaan sejarah masa lalu, maka ke depan perlu lebih dimantapkan lagi oleh kesamaan cita-cita, pandangan hidup, harapan, dan tujuan tentang masa depannya.

Dalam perspektif negara- bangsa, empat paradigm fungsi yang dikemukakan oleh Parson tersebut setidaknya perlu diterapkan oleh masyarakat Indonesia, terutama untuk menjaga nilai-nilai Pancasila agar dapat tetap hidup dan berkembang dalam kedudukannya sebagai dasar negara dan ideologi nasional bangsa Indonesia. Seperti yang telah dijelaskan sebelumnya, nilai-nilai Pancasila seakan terlupakan sebagai sebuah dasar negara dan ideologi nasional yang seharusnya dijunjung tinggi oleh semua masyarakat Indonesia, terlebih dengan semakin cepatnya perkembangan zaman yang diimbangi oleh derasnya arus globalisasi dan masuknya budaya asing. Oleh sebab itu, agar Pancasila sebagai dasar negara dan ideologi bangsa tetap mempunyai semangat untuk diperjuangkan, kita perlu menerima kenyataan jika Pancasila belum dapat dijadikan sebagai pijakan dalam bersikap oleh semua pihak. Pancasila perlu disosialisasikan agar benar-benar dipahami oleh masyarakat Indonesia khususnya kaum muda sebagai landasan filosofis bangsa Indonesia dalam mempertahankan eksistensi dan mengembangkan dirinya menjadi bangsa yang sejahtera dan modern (Yudhanegara 2015).

Globalisasi telah memberikan tantangan baru yang mau tidak mau harus di hadapi dan di sikapi oleh semua elemen masyarakat. Era keterbukaan sudah mulai mengakar kuat di era globalisasi seperti sekarang ini, sehingga identitas nasional adalah salah satu bagian mutlak yang harus dipegang agar tidak hilang dan terbawa arus globalisasi. Untuk dapat mangatasi dampak-dampak yang ditimbulkan sebagai akibat dari globalisasi tersebut, maka Pancasila sebagai pandangan hidup dan dasar negara harus tetap menjadi pijakan dalam bersikap. Karena Pancasila yang dijadikan sebagai dasar negara dan ideologi nasional bangsa Indonesia, memiliki posisi yang abadi di dalam jiwa bangsa Indonesia (Yudhanegara 2015)

\section{SIMPULAN}

Keefektifan dalam komunikasi yang terjadi pada era kemajuan IT media sosial saat ini membuktikan bahwa potensi untuk semakin besarnya pengaruh kebudayaan asing yang dapat diterima oleh masyarakat Indonesia. Kita tidak mengetahui kebudayaan seperti apa yang datang dari luar Indonesia yang kemudian akan diterima bahkan menggantikan kebudayaan dan jati diri masyarakat, khususnya para remaja yang masih memiliki pemikiran yang cenderung belum stabil dan cenderung kurang mampu memfilter antara kebudayaan yang sesuai dengan kepribadian bangsa, atau yang bertentangan dengan kepribadian bangsa Indonesia. 
Masuknya budaya asing ke suatu negara sebenarnya merupakan hal yang wajar, asalkan budaya tersebut sesuai dengan kepribadian bangsa namun kita harus tetap menjaga agar budaya kita tidak luntur, banyak kebudayaan asing yang tidak sesuai dengan kepribadian bangsa. Langkah-langkah untuk mengantisipasinya adalah antara lain dengan cara diantaranya adalah menanamkan dan mengamalkan nilai- nilai Pancasila dengan sebaik- baiknya

Oleh sebab itu, pengaruh kebudayaan asing atau nilai dan norma asing yang tersebar di internet khususnya pada media sosisal perlu di filter dengan Pancasila sebagai dasar negara dan ideologi bangsa. Maka dari itu kita harus mempunyai semangat untuk memeprjuangkan pancasila yang kenyataannya bahwa Pancasila belum dapat dijadikan sebagai pijakan dalam bersikap oleh semua pihak. Oleh sebab itu Pancasila perlu disosialisasikan agar benar-benar dipahami oleh masyarakat Indonesia khususnya kaum muda sebagai landasan filosofis bangsa Indonesia dalam mempertahankan jati diri bangsa agar tidak tergantikan dengan nilai dan norma asing yang jauh dari pribadi bangsa Indonesia.

\section{DAFTAR PUSTAKA}

Anonim. (2020). Makna Pancasila Sebagai Pandangan Hidup. Desember 4. Accessed April 16, 2021. https://indomaritim.id/.

Anonim. (2016). PENGARUH BUDAYA ASING. 17 Agustus. Diakses April 18, 2021. http://kesbangpol.riau.go.id/media.php?p=detail_artikel\&id=207.

Ardiwijaja, Roby. t.thn. Arkeowisata Mengembangkan Daya Taruk Pelestariian Warisan Budaya.

bpcbsumbar. (2017). Teknologi Informasi (Media Sosial) untuk Publikasi Cagar $\begin{array}{lllll}\text { Budaya. } & 30 \quad \text { Agustus. Diakses April 2021, } 2021 .\end{array}$ https://kebudayaan.kemdikbud.go.id/bpcbsumbar/pemanfaatan-media-sosialuntuk-publikasi-cagar-budaya/.

Effendy, Onong Uchana. (2002). Ilmu Komunikasi Teori dan Praktek. Bandung: PT Remaja Rosdakarya.

Fuchs, C. (2014). Social media a critical introduction. Los Angeles: SAGE Publication, Ltd.

Kaelan, \& Zubaidi Ahmad. (2007). Pendidikan Kewarganegaraan untuk Perguruan Tinggi. Yogyakarta: Paradigma.

Mubah, A. S. (2011). "Strategi Meningkatkan Daya Tahan Budaya Lokal dalam Menghadapi Arus Globalisasi." Jurnal Unair 302-308.

Mulawarman, Aldia Dyas Nurfitri. (2017). "Perilaku Pengguna Media Sosial beserta Implikasinya Ditinjau dari Perspektif Psikologi Sosial Terapan ." Buletin Psikologi 36-44.

Nurrizka, Annisa Fitrah. (2016). "Peran Media Sosial di Era Globalisasi Pada Remaja di Surakarta Suatu Kajian Teoritis dan Praktis Terhadap Remaja dalam Perspektif Perubahan Sosial." Jurnal Analisa Sosiologi 28-37.

Octavian, Wendy Anugrah. (2018). Jurnal Bhineka Tunggal Ika 123-128.

Parsons, Talcott. (2007). Social System.

RI, Kemenkes. 2018. Menkes: Remaja Indonesia Harus Sehat. 15 Mei. Diakses April 16, 2021. https://www.kemkes.go.id/article.

Rustian, Rafi Saumi. (2012). Apa itu Sosial Media. 1 Maret. Diakses April 18, 2021. http://www.unpas.ac.id/apa-itu-sosial-media/.

Sodik, Putri Shintia Joice Bolu. Muhamad Ali. n.d. "Pengaruh Budaya Asing Terhadap Perilaku Remaja." IIK STRADA INDONESIA.

Supratman, Lucy Pujasari. (2018). "Penggunaan Media Sosial oleh Digital Native." Jurnal IImu Komunikasi 47-60. 
Syahril Muhammad, Mhd. Asikin Kaimudin. (2019). "Perilaku Penyimpangan Sosial pada Kalangan remaja Kelurahan Akehuda Kota Ternate Utara." GeoCivic Jurnal 206-210.

Sztomka, P. (2004). Sosiologi Perubahan Sosial. Jakarta: Kencana Prenada Media Group.

Triyogo, Heru. (2019). "Peran Teknologi Informasi di Era Revolusi Industri 4.0." Kompasiana. 29 Juni. https://www.kompasiana.com/herutriyogo77/5d175851097f366a1f53ab23/peran -teknologi-informasi-di-era-revolusi-industri-4-0.

Wilga Secsio Ratsja Putri, R. Nunung Nurwati, \& Meilanny Budiarti S. t.thn. "PENGARUH MEDIA SOSIAL TERHADAP PERILAKU REMAJA." PROSIDING KS: RISET \& PKM 1-154.

Yudhanegara, H. Firman. (2015). "Pancasila Sebagai Filter Pengaruh Globalisasi Terhadap Nilai-Nilai Nasionalisme." Jurnal IImu Administrasi Negara 165-180. 